\title{
Studije
}

Pregledni članak UDK 27-1(045)

doi: $10.21464 /$ fi40108

Primljeno 18. 5. 2019.

\section{Žarko Ament}

Lojenov prilaz 4, HR-10020 Zagreb

zarko.ament@gmail.com

\section{Vertikalne strukture kršćanskog režima istine}

\begin{abstract}
Sažetak
Rad analizira formaciju moći kršćanskog režima istine promatrajući je u kontekstu Foucaultova pojma strategijskih cjelina. Posebno se analizira seksualna formacija moći kroz tri žarišne točke njezina djelovanja. Prva se žarišna točka formira unutar sukoba starozavjetnog režima istine i kanaanskog kulta plodnosti. Druga žarišna točka formirana je pod utjecajem antičke filozofske misli, ponajprije na filozofiji stoika, na ideji o uzdržavanju od seksualnog čina kao otvaranju božanskoj inspiraciji te medicinskim spoznajama antike. Treća žarišna točka formira se oko mehanizama kontrole kršćanskog režima istine kroz klasifikaciju, regulaciju, zabranu, tarifiranje prijestupa i korekcije nauka. Zadaća je formacije moći vertikalno strukturiranje režima istine u njezinoj antropomorfnoj $i$ androcentričnoj imanentnosti.
\end{abstract}

\section{Ključne riječi}

kršćanski režim istine, Michel Foucault, strategijska cjelina, seksualna formacija moći

\section{Uvod}

U suvremenim teološkim razmatranjima odgovor na pitanje porijekla kršćanskih istina pronalazi se u božanskom nadahnuću, gdje je ono nezamjenjiv element koji usmjerava proizvodnju tih istina. Iako taj odgovor zadovoljava pojedinca koji ga prihvaća u vjeri, gdje jamstvo za njegovu istinitost daje Bog, mi krećemo iz druge pozicije. Za razliku od teoloških razmatranja, u svojoj smo analizi uočili postojanje režima istine koji je dinamički i androcentrično ${ }^{1}$ oblikovan te koji je pod utjecajem raznih odnosa moći. Nadovezu1

Možemo se složiti s definicijom Sandre Lipsitz Bem koja androcentrizam definira kao privilegiranje muškog, a marginaliziranje ženskog iskustva, gdje se muško iskustvo postavlja kao standard kulture dok se žene i žensko iskustvo tretira kao odstupanje od tog standarda. Usp. Sandra Lipsitz Bem, The Lenses of Gender: Transforming the Debate on Sexual Inequality, Yale University Press, New Haven 1993., str. 41. Kratki pregled ovog koncepta donose Galić i Nikodem. Usp. Branka Galić, Krunoslav Nikodem, »Ne/razlomljeni identiteti: seksizam i religioznost u hrvatskom društvu«, Socijalna ekologija 15 (2006) 1-2, str. 81-102, str. 82-84. 
jući se na Foucaultov pojam režima istine, u genealoškoj analizi kršćanskog režima istine uočavamo postojanje vertikalnih struktura koje usmjeruju proizvodnju znanja unutar njega. Vertikalnost se očituje u odnosu na cjelokupnu strukturu režima istine. Pod time mislimo da su ove strukture prisutne u ranim fazama oblikovanja režima istine, ali i u kasnijim fazama u suvremenosti. Primjer vertikalne strukture kršćanskog režima istine možemo uočiti u seksualnoj formaciji moći, koju ćemo metodološki razložiti kroz tri žarišne točke. Vertikalno djelovanje tako uočavamo u tekstovima Starog zavjeta, koji će biti bitan segment kršćanskog režima istine, ali i kasnije u dinamici diskurzivne proizvodnje kroz razne teološke akumulacije. Ključna je odlika ove strukture antropomorfno i androcentrično vrednovanje seksualnosti, koja se u značajnoj mjeri regulira nizom mehanizama kontrole kršćanskog režima istine.

\section{Kršćanski režim istine}

Foucaultov bi se istraživački rad mogao podijeliti u tri velika područja. Prvo je područje njegova analiza arheologije, koja obuhvaća djela napisana od 1961. do 1969. godine, u kojima analizira dominantne oblike racionalnosti. ${ }^{2}$ Drugo je područje genealogije, unutar kojega analizira modalitete moći na liniji Nietzscheove genealogije u razdoblju od 1971. do 1976. godine. Naglasak se stavlja na površinsku analizu određenih obrazaca i povijesnih situacija bez ulaska u esencijalističku analizu, ne traži se neka skrivena bit, nego ono što se događa u oblikovanju percepcije. ${ }^{3}$ Treće je područje analize etika, koja nastupa u zadnjoj fazi Foucaultova stvaralačkog djelovanja i traje do njegove smrti. ${ }^{4}$ Za naše istraživanje bit će posebno važno područje genealogije zbog Foucaultove analize modaliteta moći koji tvore strukturu kršćanskog režima istine.

Foucault je analizi seksualnosti posvetio dosta svog istraživačkog rada. Uza sve relevantne radove koji pokrivaju ovu tematiku i koje spominjemo u ovom radu, posebno je značajno njegovo posthumno i nedavno objavljeno djelo Les aveux de la chair (Priznanja put), koje se bavi analizom braka, djevičanstva i seksualnosti u prvim četirima stoljećima postojanja kršćanstva te je četvrti dio njegove Povijesti seksualnosti. Treba imati na umu da određeni autori smatraju da Foucault u svojoj analizi seksualnosti zauzima mušku perspektivu, što Carrette smatra jednim od važnijih problema njegova istraživačkog rada. ${ }^{5}$ Iako djelomično možemo prihvatiti ovu kritiku, treba imati na umu da je ključna odlika kršćanskog režima istine androcentrična pozicioniranost, a položaj žene unutar režima onaj je nijemog subjekta. Tako u Prvoj poslanici Korinćanima čitamo:

»Kao u svim Crkvama svetih, žene na sastancima neka šute. Nije im dopušteno govoriti, nego neka budu podložne, kako i Zakon govori. Žele li što saznati, neka kod kuće pitaju svoje muževe jer ružno je da žena govori na sastanku.« (1 Kor 14,35)

Upravo je zbog navedenog diskurs unutar režima istine, koji se formira oko seksualnosti, strogo definiran muškom perspektivom te je Foucault u njegovu prikazu bio u velikoj mjeri ograničen. S obzirom na činjenicu da Foucaultov istraživački rad ostaje nedovršen zbog njegove prerane smrti, ostaje otvoreno pitanje bi li neka njegova buduća istraživanja uzela u obzir i položaj žene te ga sustavno analizirala. Na ovom je tragu i Senellart, koji na kritiku da je Foucaultova analiza ranog kršćanstva nedovoljno opširna jer ne uključuje kerygmu, navještaj života i djela Isusa Krista, a koja zauzima važno mjesto u tekstovima koje on obrađuje i važna je za teologiju, odgovara da se Foucault u svojim istraživanjima usmjerio na analizu moralnog učenja i njegove 
političke moći, čime prikazuje kršćanstvo u novom kontekstu. ${ }^{6}$ Za njega je analitičko vrednovanje kerygme bilo od sekundarne važnosti, a u prvi plan dolaze mehanizmi diskurzivne proizvodnje režima istine.

Režim istine jedan je od najmanje razrađenih Foucaultovih pojmova te kao pojam prolazi određenu transformaciju u kasnijem teorijskom razvoju. Pojam režima istine Foucault prvi puta uvodi 1975. godine kao odrednicu opće politike istine. Pod tim smatra da svako društvo ima svoj režim istine, svoju opću politiku istine. ${ }^{7}$ Nakon 1979. godine Foucault režim istine pozicionira u područje subjektiviteta. Tako u njegovim kasnijim radovima režim istine određuju obveze pojedinca prema procedurama manifestacije istine, gdje stavlja naglasak na ulogu koju subjekt igra u odnosu istine i njega samog.

Foucault pojam režima istine prvi put upotrebljava u prvom poglavlju djela Nadzor i kazna: rađanje zatvora, u kojem, govoreći o novom kaznenom sustavu 18. i 19. stoljeća, ističe stvaranje formacija znanja i znanstvenog diskursa koje se stavlja u svrhu sustava kažnjavanja, napominjući da dolazi do pojave novih režima istine. ${ }^{8}$ Ono što karakterizira nove režime istine jest promjena kaznenog stila. U razdoblju kraćem od jednog stoljeća tijelo osuđenika koje je bilo podvrgnuto mukama i sakaćenju te kao takvo javno prikazivano nestaje kao glavna meta represije. Kažnjavanje tako prestaje biti predstavom u kojoj se uprizoruje sva moć kaznenog sustava, gdje se manifestnim divljaštvom nad tijelom osuđenika pokušava zasjeniti počinjeni zločin. ${ }^{9}$ Kažnjavanje postaje najskrovitiji dio kaznenog procesa, u kojem se više ne stavlja naglasak na njegovu brutalnost, nego na njegovu neminovnost. Svaki zločin mora biti kažnjen. Nestanak mučenja za sobom povlači i drugačiji odnos prema tijelu osuđenika te se s njega uklanja fokus. Tijelo postaje oruđe; ako se na njega djeluje, to se čini radi zatvaranja, da bi ga se lišilo slobode, koja je u isto vrijeme pravo i dobro. ${ }^{10}$ Tako se kažnjavanje pretvara u ekonomiju oduzetih prava, dok se istovremeno napušta umijeće izazivanja boli.

Ovdje se nazire pitanje koje Foucaulta u velikoj mjeri zaokuplja u razmatranju odnosa moći i istine, a postavlja ga u seminaru Treba braniti društvo: kako diskurs istine utemeljuje granice prava moći? ${ }^{11}$ Društvo kao takvo odre-

Usp. Rade Kalanj, »Humanističke znanosti i problem moći: Foucaultov pristup«, u: Michel Foucault, Znanje i moć, preveo Rade Kalanj, Globus, Zagreb 1994., str. 173-181, str. 176; Carlos G. Prado, Searle and Foucault on Truth, Cambridge University Press, New York 2006., str. 70.

Usp. R. Kalanj, »Humanističke znanosti i problem moći«, str. 176; te Michel Foucault, »Nietzsche, Genealogy, History«, u: Donald F. Bouchard (ur.), Language, Counter-Memory, Practice: Selected Essays and Interviews, Cornell University Press, Ithaca 1977. str. 140 .

Usp. C. G. Prado, Searle and Foucault on Truth, str. 70 .

5

Usp. Jeremy R. Carrette, Foucault and Religion: Spiritual Corporality and Political Spirituality, Routledge, London 2000., str. 83.
6

Usp. Michel Senellart, »Michel Foucault: une autre histoire du christianisme?«, Les nouveaux horizons de l'ecclésiologie: du discours clérical à la science du social (29. 3. 2013.). Dostupno na: https://journals.openedition.org/ cem/12872\#text (pristupljeno: 18. 8. 2019.).

7

Usp. Michel Foucault, Surveiller et punir: Naissance de la prison, Gallimard, Pariz 1975., str. 23.

8

Usp. ibid.

9

Usp. ibid., str. 11.

10

Usp. ibid.

11

Usp. Michel Foucault, »Society must be defended «: Lectures at the Collège de France, 1975-76, Penguin Books, London 2004., str. 24. 
đuju mnogostruki odnosi moći neodvojivi od diskursa istine. Moć ne može biti utemeljena ako njome ne upravlja određeni diskurs istine strukturiran ekonomijom istine. Upravo u uspostavljanju režima istine kristalizira se moć imenovanja istinitog i lažnog, kojoj Foucault daje političku dimenziju. Režim istine ima sebi svojstvenu opću politiku istine:

$» . .$. tj. tipove diskursa koje [društvo] prihvaća i čini da funkcioniraju kao istiniti; mehanizme i instance koji omogućuju da se razlikuju istiniti ili pogrešni izričaji, način na koji se sankcioniraju jedni i drugi; tehnike i postupke koji se koriste da se dođe do istine; status onih koji su zaduženi za to da naznače ono što funkcionira kao istinito. ${ }^{12}$

Suvremena društva karakterizira politička ekonomija istine ${ }^{13}$ kojom se odjeljuje istinito od lažnog. Nadalje Foucault pojašnjava što karakterizira političku ekonomiju istine:

»Istina je usredotočena na formu znanstvenog diskursa i na institucije koje ga proizvode; podčinjena je konstantnom ekonomskom i političkom poticanju (potreba za istinom, kako ekonomske proizvodnje tako i političke moći); objekt je, u raznim oblicima, difuzije i neizmjerne potrošnje (kruži odgojnim i informacijskim ustanovama čija je rasprostranjenost u socijalnom tijelu relativno velika, usprkos nekim ograničenjima); proizvedena je i prenošena pod kontrolom, ne ekskluzivnom ali dominantnom, malog broja velikih političkih i ekonomskih aparata (univerzitet, vojska, mass medija); konačno, ona je ulog u igri čitave jedne političke debate i jednog socijalnog sukoba ('ideološke' borbe). «14

Političku ekonomiju istine treba promatrati kao mrežu odnosa moći unutar kojih se proizvodi diskurs. U tom kontekstu i kršćanski režim istine treba promatrati kao kompleksan sustav sastavljen od raznih mehanizama moći. On nije monolitno oblikovan u smislu da se istina proizvodi iz jednog centra, već se radi o dinamičkoj mreži odnosa i raznovrsnih izvora moći koji ga pozitivno ili negativno oblikuju. Pozitivno oblikovanje uključuje istinu nastalu kao produkt izvora moći unutar režima, dok je negativno oblikovanje nastalo kao reakcija na vanjske utjecaje.

Postavlja se pitanje kako Foucault definira pojam istine. Carlos G. Prado uočava da Foucaultov relativizam nije irealizam te ističe da je upotreba pojma istine kod njega višedimenzionalna. ${ }^{15}$ On razlikuje pet različitih načina Foucaultove upotrebe pojma istine. Prva je kriterijska upotreba, koja se odnosi na Foucaultovu tezu prema kojoj svako društvo ima svoj režim istine. ${ }^{16}$ Prado ističe da se ovdje radi o određenom kulturalnom relativizmu koji se može poklapati s objektivističkim pogledom na istinu. Druga je upotreba konstruktivistička, koja gravitira oko Foucaultove teze da moć proizvodi diskurs. ${ }^{17}$ Ova upotreba odnosi se jednako na skrivenu istinu i prividnu istinu. ${ }^{18}$ Dok kriterijska upotreba dopušta razliku između ideološke istine i skrivene istine, ta razlika ne postoji kod konstruktivističke upotrebe pojma istine. Moć ne proizvodi istinu iz jednog središta i sustavno, već se ona proizvodi nasumično kroz mrežu odnosa moći. ${ }^{19}$ Treća je Foucaultova upotreba pojma istine perspektivistička, koja istinu smješta u područje interpretacije. ${ }^{20}$ Foucault je pritom u skladu s Nietzscheovim perspektivizmom, koji niječe bilo kakvu mogućnost sveobuhvatnog opisa svijeta koji bi mogao pomiriti različite istinite perspektive, uz uvažavanje činjenice da se Foucault ovdje ne izjašnjava o izvanjezičnoj i izvandiskurzivnoj stvarnosti. ${ }^{21}$ Prado ovdje navodi:

»Foucaultovo ničeansko pitanje o vrijednosti istine ne smijemo interpretirati površno. (...) Nietzscheovo je pitanje zašto mislimo da je uvijek jedna interpretacija ispravna i zašto dajemo visok prioritet $\mathrm{i}$ vrijednost postizanju te jedinstveno ispravne interpretacije. $\ll^{22}$

Četvrta je upotreba pojma istine kod Foucaulta iskustvena upotreba, sadržana u odnosu razumijevanja i rješenja. ${ }^{23}$ Prado pojašnjava da se ovdje radi o neče- 
mu što smo osvijestili da vjerujemo, a nije bilo artikulirano prije, ili kada neku dvosmislenu ideju razriješimo nečim novim što smo naučili. Ovdje se ne radi o nečemu što je stečeno kroz ispitivanje ili analiziranje nečega, već o tome da nešto vidimo drugačije zbog određenog iskustva. ${ }^{24}$ Peta upotreba pojma istine ona je prešutnog realista, koju Foucault upotrebljava svega nekoliko puta i to u objektivističkom kontekstu. ${ }^{25}$ Iako neki autori smatraju da se radi o nekonzistentnosti Foucaultove upotrebe pojma istine, Prado smatra da je u ovoj poziciji njegov stav onaj prešutnog realista. ${ }^{26}$

Važno je naglasiti da kršćanski režim istine treba promatrati u nešto širem kontekstu nego samo kršćanstvo. Njegovu jezgru ne čini samo ono znanje koje je proizvedeno nastupom kršćanstva nego treba uključiti i sve ono što je proizvedeno i prije samog kršćanstva te je uspješno internalizirano u njega. Možemo zamijetiti da jezgru kršćanskog režima istine čini ono znanje koje je proizvedeno unutar starozavjetnog režima istine ${ }^{27}$ te se kršćanski režim istine gradi oko njega. Kršćanski režim istine sastavljen je od unutrašnje jezgre, koja sadrži znanje proizvedeno u starozavjetnom režimu istine, vanjske jezgre, koja nastaje djelovanjem prvih kršćanskih teoloških struja i proizvodi znanje iz kojega se, između ostalog, oblikuju predaje kasnije zapisane u knjigama Novog zavjeta, te vanjskih slojeva, koje treba promatrati kao kasnije teološke iteracije koje traju sve do suvremenosti. Kao što ćemo istaknuti u daljnjem tekstu, ovakvo strukturiranje kršćanskog režima istine zamjećujemo unutar seksualne formacije moći prilikom definiranja dopuštenog seksualnog čina. Nezamjenjiv element samog čina jest prokreacija, gdje je seksualni čin kao takav definiran u starozavjetnom režimu istine te postaje dio unutrašnje jezgre kršćanskog režima istine. Osim unutrašnje jezgre, seksualna formacija moći tako prokreaciju kao svrhu seksualnog čina pozicionira i u vanjsku jezgru, ali i u vanjske slojeve kršćanskog režima istine. Ovdje zamjećujemo da je proizvodnja znanja unutar kršćanskog režima istine u značajnoj mjeri usmjerena onim već postojećim znanjem starozavjetnog režima istine.

12

Michel Foucault, Znanje i moć, preveo Rade Kalanj, Globus, Zagreb 1994., str. 160.

13

Usp. ibid.

14

Ibid., str. 161

15

Usp. C. G. Prado, Searle and Foucault on Truth, str. 82.

16

Usp. ibid., str. 83.

17

Usp. ibid., str. 84.

18

Usp. ibid.

19

Usp. ibid., str. 85.

20

Usp. ibid., str. 87.

21

Usp. ibid.
22

Ibid., str. 89.

23

Usp. ibid., str. 93.

24

Usp. ibid. Prado ovdje navodi Foucaultove primjere iskustvene upotrebe istine koji se javljaju kada se perspektiva mijenja pod utjecajem mučenja ili suđenja borbom, gubitka religijske ili političke vjere ili izdaje od strane prijatelja. Usp. ibid., str. 94.

25

Usp. ibid., str. 96.

26

Usp. ibid., str. 100.

27

Kada govorimo o starozavjetnom režimu istine treba imati na umu da, iako se koristi pojam koji se referira na knjige Starog zavjeta, ovdje ne mislimo samo na biblijske tekstove nego i na teološke predaje i sve one druge procese koji čine režim istine kao takav. Riječ je o mreži odnosa moći koja dinamički i fluidno oblikuje režim istine. 
Upravo u navedenom treba promatrati vertikalno svojstvo formacije moći. Vertikalnost se odnosi na strukturu režima istine, na odnos koji nastaje ako imamo u vidu unutrašnju i vanjsku jezgru te vanjske slojeve kršćanskog režima istine. Kao što ćemo istaknuti u analizi žarišnih točaka seksualne formacije moći, njezino je djelovanje vertikalno ako ga promatramo u odnosu na strukturu cjelokupnog režima istine. Formacije moći odgovaraju Foucaultovu pojmu strategijskih cjelina, koje on uočava u procesu formiranja znanja o seksu. Formacije moći tako vertikalno prošivaju režim istine usmjerujući proizvodnju znanja. Tu treba imati na umu da formacije moći ne djeluju iz jednog izvora, već je riječ o strategijskom oblikovanju procesa proizvodnje istine. $\mathrm{Na}$ primjeru seksualnog čina kao onoga kojemu je svrha prokreacija, vertikalnost uočavamo u definiranju čina kao takvog u cijeloj strukturi režima istine, koja uključuje njegovu unutrašnju i vanjsku jezgru te vanjske slojeve.

Pojašnjavajući dinamiku odnosa moći i znanja, Foucault objašnjava da se ne radi o skupu institucija ili aparata koje onda podčinjavaju građane, već o odnosu snaga koje su formirane oko nekog strategijskog polja. U tom kontekstu formacije moći kršćanskog režima istine, treba promatrati kao polja koja definiraju mrežu odnosa moći unutar kojih se proizvodi znanje.

»Tamo gdje postoji moć postoji i otpor. (...) U odnosu na moć ne postoji jedno mjesto velikog odbijanja - duša pobune, žarište svih buna, razni otpori različitih vrsta: mogući, nužni, nevjerojatni, spontani, divlji, usamljeni, usklađeni, podmukli, nasilni, nepomirljivi, spremni na pogodbu, koristoljubivi, žrtveni. Oni po definiciji mogu postojati samo u strategijskom polju odnosa moći. «28

Foucault ističe da moć u analizi odnosa moći ne možemo promatrati kao onu koja izvire iz jednog izvora, već treba slijediti četiri pravila koja omogućavaju sagledavanje odnosa moći koji egzistiraju unutar neke strategijske cjeline. Prvo je pravilo imanencije, koje tvrdi da ako se seksualnost uspostavila kao područje koje treba spoznati, to se dogodilo zbog odnosa moći koji ju utemeljuju kao takvu. ${ }^{29}$ Prema tome, u analizi treba krenuti od lokalnih žarišta moći-znanja. ${ }^{30}$ Drugo je pravilo neprekinutih mijena, prema kojem ne treba tragati za tim tko ima moć, već za shemom mijena što ih samim svojim djelovanjem uključuju odnosi snaga. ${ }^{31}$ Treće je pravilo dvostruke uvjetovanosti, prema kojemu nijedno lokalno žarište, nijedna shema preobrazbe ne može funkcionirati ako se ne uvrsti u cjelovitu strategiju. ${ }^{32}$ Četvrto je pravilo taktičke polivalentnosti diskursa, prema kojem se moć i znanje artikuliraju u diskursu te treba dopustiti složenu i nestalnu igru, gdje diskurs može istovremeno biti sredstvom i posljedicom moći, ali i zaprekom, točkom otpora i polazištem za neku oprečnu strategiju. ${ }^{33}$

\section{Formacija moći režima istine}

Kada govorimo o formaciji moći režima istine, kao što smo već istaknuli, ona se u velikoj mjeri poklapa s pojmom strategijskih cjelina, koje Foucault zamjećuje u procesu formiranja znanja o seksu. Strategijske su cjeline prostor unutar kojega se odvija dinamika odnosa moći. Foucault navodi da strategijske cjeline nastaju postepeno, uočava se njihova relativna autonomnost $\mathrm{i}$ mogu se klasificirati kao histerizacija ženskog tijela, pedagogizacija dječjeg seksa, socijalizacija prokreativnih ponašanja te psihijatrizacija nastranog užit$\mathrm{ka}^{34} \mathrm{Na}$ tom tragu uočavamo formacije koje upravljaju diskurzivnom proizvodnjom unutar kršćanskog režima istine. ${ }^{35}$ Treba naglasiti da one ne djeluju iz jednog izvora, već se radi o fluidnom sustavu podložnom promjenama. 
Da bismo u potpunosti shvatili mehanizam proizvodnje istine u kršćanskom režimu istine, moramo razložiti temelje moći samog režima. Moć inherentna režimu, kao ona koja proizvodi diskurs, artikulira se kroz spektar procedura stvorenih sa zadaćom ograničavanja, kontroliranja i multipliciranja diskurzivne proizvodnje. Ovdje je važno istaknuti da moć nije fokusirana u jednoj točki, niti postoji binarna opreka između režima istine i subjekta koji je zahvaćen njegovim djelovanjem. Prije bi se moglo govoriti o cijelom spektru odnosa snaga koji se međusobno prožimaju stvarajući time igru moći unutar određenih strategijskih polja ili formacija diskurzivnih praksi.

\section{Seksualna formacija moći}

Promatrajući dinamiku diskurzivne proizvodnje kršćanskog režima istine zamjećujemo da se proces proizvodnje znanja oblikuje oko triju žarišnih točaka seksualne formacije moći. Prva se formira oko ideološkog sukoba starozavjetnog režima istine i kanaanskog kulta. ${ }^{36}$ Proizvod je tog sukoba narativ o iskonskom grijehu, u čije se središte pozicionira seksualni čin kao simbol otpada od vjere u pravog i jedinoga Boga. Druga žarišna točka formira se na antičkoj misli, čiji utjecaj, kanalizirajući se kroz seksualnu formaciju moći, daje bitan oblik kršćanskom režimu istine koji je u procesu nastanka. Tu se prije svega vidi utjecaj filozofije stoika, koncepta uzdržavanja od seksa kao otvaranja kanalu božanske inspiracije, te antičkih medicinskih spoznaja, koje seksualni čin vide kao štetan za psihofizičko zdravlje čovjeka. Konačno, treća žarišna točka formira se oko mehanizama kontrole kršćanskog režima istine. Ti mehanizmi kontrole nalaze svoj izričaj u klasifikaciji, regulaciji, zabrani, tarifiranju prijestupa i korekcijama nauka kroz razne procese proizvodnje istine svojstvene režimu. Ono što zamjećujemo jest da se prva žarišna točka oblikuje prije nastanka kršćanskog režima istine, druga u trenutku njegova nastajanja, a treća nakon nastanka kršćanskog režima istine. Kroz tri navede-

28

M. Foucault, Volja za znanjem, str. 67.

29

Usp. ibid., str. 69.

30

Usp. ibid.

31

Usp. ibid.

32

Usp. ibid., str. 70 .

33

Usp. ibid., str. 70-71.

34

Usp. ibid., str. 72-73.

35

Dok Foucault upotrebljava pojam strategijske cjeline da bi opisao polja unutar kojih se odvija dinamika moć - znanje u kontekstu seksualnosti, u svojoj smo analizi odlučili napraviti mali odmak od tog pojma i koristiti pojam formacija moći. Iako se pojam formacija moći poklapa s Foucaultovim pojmom strategijskih cjelina, koji koristi u općem kontekstu seksu- alnosti, mi ga koristimo u kontekstu kršćanskog režima istine, gdje je seksualna formacija moći jedna od osam različitih formacija moći koje definiraju dinamiku moć - znanje. U kršćanskom režimu istine uočavamo legalističku formaciju moći, seksualnu formaciju moći, dijetetičko-sanitarnu formaciju moći, antiparezijsku formaciju moći, militarističku formaciju moći, monetarnu formaciju moći i antisemitsku formaciju moći. Te formacije moći čine vertikalne strukture kršćanskog režim istine te se detaljnije razrađuju u neobjavljenoj doktorskoj disertaciji Strukturalistička analiza kršćanskog koncepta grijeha $i$ »režim istine«. Zbog propozicija ovog rada ograničili smo se na analizu samo seksualne formacije moći.

36

Kanaanski kult označavao je ritualne prakse zapadnosemitskih naroda: Aramejaca, Kanaanaca, Feničana, Kartažana. Razvija se pod utjecajem egipatske i mezopotamskih religija. Usp. Adalbert Rebić (ur.), Opći religijski leksikon: $A-\check{Z}$, Leksikografski zavod Miroslav Krleža, Zagreb 2002., str. 419. 
ne žarišne točke seksualna formacija moći antropomorfno oblikuje kršćanski režim istine zauzimajući androcentričnu perspektivu.

\section{Prva žarišna točka seksualne formacije moći}

Spomenuta prva žarišna točka kršćanskog režima istine, formirana oko ideološkog sukoba starozavjetnog režima istine i kanaanskog kulta, dobiva tim više na značaju ako uzmemo u obzir činjenicu da je izraelski narod izložen utjecaju toga kulta još od vremena kralja Davida, i to ne samo u religijskom nego i u kulturnom smislu. Tako Rebić navodi da Izraelci, uz prakticiranje kanaanskog kulta plodnosti, preuzimaju i kanaanski jezik, koji se kasnije naziva hebrejskim. ${ }^{37}$ Da taj sukob zauzima ključno mjesto u procesima proizvodnje istine starozavjetnog režima istine, zamjećujemo i u razdoblju u kojem ta tema dominira, a koje obuhvaća period zapisivanja većine starozavjetnih knjiga. ${ }^{38} \mathrm{U}$ 9. stoljeću prije nove ere na dvoru izraelskog kralja Ahaba prisutno je 400 Baalovih i 400 Jahvinih svećenika. ${ }^{39}$ Status quo rješava se političko-religijskom čistkom kada Jehu, zapovjednik kraljevske straže, uklanja Omrijevu dinastiju i preuzima vlast podupirući jahvistički kult. ${ }^{40} \mathrm{U}$ tom je procesu pobijeno 450 Baalovih svećenika. S obzirom na to da je institucionalna potpora kanaanskom kultu značajno smanjena, jahvistički se kult $\mathrm{u}$ narednim stoljećima pozicionira u religijsko središte usmjeravajući proizvodnju znanja prema demoniziranju ostataka kanaanskog kulta prisutnog u toj religijskoj tradiciji. Tako seksualnost, koja se nalazi u samom središtu kanaanskog kulta plodnosti, počinje dobivati negativne konotacije. Da bi se uklonili tragovi kanaanskog kulta, velik se trud ulaže u proizvodnju znanja o njegovoj štetnosti, što uočavamo u knjigama Petoknjižja, u Prvoj i Drugoj knjizi o Kraljevima, Amosu, Hošei, Izaiji, gdje sukob s kanaanskim kultom zauzima značajno mjesto.

U procesu pročišćavanja religijskog kulta Izraela starozavjetni režim istine u knjizi proroka Hošee koristi metaforu braka da bi opisao i penalizirao otpad nekih subjekata koji su pod utjecajem režima. ${ }^{41}$ Jahve, koji se u režimu istine stavlja u poziciju jedinog i pravog Boga, zauzima ulogu supruga i zaručnika, dok se subjekti režima istine okupljeni u narod stavljaju u poziciju zaručnice. Neprihvaćanje istina od subjekata unutar režima interpretira se kao otpadanje od religije te simbolizira činom bludništva. Režim istine koristi čin bluda dvodimenzionalno: da bi se označio otpad od jedine i prave istine, ali i ukazalo na praksu koja je bila raširena u kanaanskom kultu, a prakticirale su je mlade djevojke. Rebić u analizi knjige proroka Hoše tako navodi da mlade djevojke žrtvuju djevičanstvo odlazeći u Baalove hramove, u kojima pomoću kultnih simbola prakticiraju spolne odnose s ciljem postizanja plodnosti u braku. ${ }^{42}$ Bludništvo kao otpad od vjere i kritika kanaanskog kulta sakralne prostitucije najbolje se uočavaju u citatu iz Hošeine knjige:

»Da, bludu se odala mati njihova, sramotila se ona koja ih zače. Da, rekla je: Trčat ću za svojim milosnicima, za njima koji mi daju kruh moj i vodu, vunu moju i lan, ulje i piće moje!« (Hoš 2,7)

$\mathrm{Na}$ ovome se mjestu u isto vrijeme ističe otpadništvo izraelskog naroda, ali i element kanaanskog kulta plodnosti. ${ }^{43}$ Prilikom prakticiranja obreda sakralne prostitucije na svetim mjestima ili hramovima, svećenici kao utjelovljenje boga Baala darivaju žene kruhom i vinom, vunom i lanom te uljem i pićem. Nemogućnost starozavjetnog režima istine da istisne utjecaj kanaanskog kulta očituje se i u zapovijedi koja nastaje stotinjak godina kasnije, a pronalazimo je u knjizi Ponovljenog zakona: 
»Sravnite sa zemljom sva mjesta na kojima su narodi koje ćete protjerati iskazivali štovanje svojim bogovima, nalazila se ona na visokim brdima, na humovima ili pod kakvim zelenim drvetom. Porušite njihove žrtvenike, porazbijajte njihove stupove, spalite im ašere; smrvite kipove njihovih bogova, zatrite im imena s onih mjesta.«(Pnz 12,2-4)

U navedenom citatu treba zamijetiti spominjanje svetog drveta kao mjesta bogoštovlja boga Baala. Taj element starozavjetni režim istine preuzima kao centralni te simbol drveta postaje glavni motiv narativa o iskonskom grijehu. Starozavjetni režim istine pretvara drvo u simbol zla upravo zbog utjecaja kanaanskog kulta. Rebić navodi da Kanaanci grade žrtvenike ispod drveća koje smatraju svetim te se na tim mjestima moli i traži zagovor božanstva uz prakticiranje sakralne prostitucije. ${ }^{44} \mathrm{U}$ knjizi proroka Hoše navodi se i vrsta drveta, tako znamo da se obredi kanaanskog kulta prakticiraju ispod drveta hrasta, jablana, duba i smrdljike. ${ }^{45}$

Sukob s kanaanskim kultom starozavjetni režim istine aktualizira u narativima formiranima oko djelovanja ostalih važnijih proroka. Tako čitajući knjige Starog zavjeta uočavamo da se Amos, Ilija, Elišej i Izaija bore za čistoću jahvističkog kulta. Unutar starozavjetnog režima istine djelovanje proroka Ilije prikazuje se kao reakcija na širenje kanaanskog kulta pod utjecajem Jezabele, žene izraelskog kralja Ahaba. Rebić navodi da Jezabela ima velik uspjeh u tome jer je velik broj pokorenih kanaanskih plemena samo prividno štovao jahvistički kult, dok su, zapravo, i dalje štovali Baala, a ponovnim legaliziranjem tog kulta počinju to raditi otvoreno. ${ }^{46}$ Hramska prostitucija počinje se prakticirati u jahvističkim hramovima u Betelu, Danu i drugdje, dok u isto vrijeme na dvoru kralja Ahaba boravi oko 400 Baalovih i 400 Jahvinih svećenika. Starozavjetni režim istine sukob Ilije i kanaanskog kulta najjasnije prikazuje u trenutku odmjeravanja snaga boga Baala i boga Jahve. Ilija moli

37

Usp. Adalbert Rebić, Prorok $i$ njegova preljubnica: (Hoš 1-4): metafora braka u službi proročke poruke, Kršćanska sadašnjost, Zagreb 2005., str. 42-43.

38

Usp. Adalbert Rebić, Jerko Fućak, Bonaventura Duda (ur.), Jeruzalemska Biblija: Stari $i$ Novi zavjet $s$ uvodima $i$ bilješkama iz »La Bible de Jerusalem«, Kršćanska sadašnjost, Zagreb 2001., str. 1059.

39

Usp. Adalbert Rebić, Prorok čovjek Božji, Kršćanska sadašnjost, Zagreb 1996., str. 34.

40

Usp. A. Rebić, Prorok i njegova preljubnica, str. 45.

41

U knjizi proroka Hošee, koja nastaje nekoliko stoljeća prije narativa o padu, starozavjetni režim istine problematizira utjecaj kanaanskog kulta. Režim istine koristi metaforu bračne nevjere da bi odgovorio subjekte od štovanja nedopuštenog kulta. Slično kao i u narativu o padu, tekst govori o prekidu veze s Bogom. »Početak riječi Jahvinih Hošei. Jahve reče Hošei: 'Idi, oženi se bludnicom i izrodi djecu bludničku, jer se zemlja bludu odala, odmetnuvši se od Jahve!' I on ode, uze Go- meru, kćer Diblajimovu, koja zače i rodi mu sina. Jahve mu reče: 'Nadjeni mu ime Jizreel, jer još samo malo i kaznit ću pokolje jizreelske na domu Jehuovu i dokončat ću kraljevstvo doma Izraelova. I u taj dan slomit ću lûk Izraelov u dolini jizreelskoj.' I ona opet zače i rodi kćer. I reče mu Jahve: 'Nadjeni joj ime Nemila, jer mi odsad neće biti mila kuća Izraelova, od nje ću se povući; a omiljet će mi kuća Judina, spasit ću je Jahvom, Bogom njihovim, a neću je spasiti lûkom, mačem ni kopljem, ni konjima ni konjanicima.' Kad odoji Nemilu, zače opet i rodi sina. I reče Jahve: 'Nadjeni mu ime Ne-narod-moj, jer više niste narod moj i ja vama nisam više Onaj koji jest'.« - Hoš 1,2-9.

42

Usp. A. Rebić, Prorok i njegova preljubnica, str. 10 .

43

Usp. ibid., str. 66-69.

44

Usp. ibid., str. 107.

45

Usp. ibid.

46

Usp. A. Rebić, Prorok čovjek Božji, str. 34. 
boga Jahvu da prihvati njegovu žrtvu i donese mu pobjedu u borbi s Baalovim svećenicima, što se prema kazivanju predaja starozavjetnog režima istine i događa. Kao rezultat tog dvoboja čitamo:

»Ilija im reče: 'Pohvatajte proroke Baalove da nijedan od njih ne utekne!' I oni ih pohvataše. Ilija ih odvede do potoka Kišona i ondje ih pobij.« $(1 \mathrm{Kr} 18,40)$

Iako se ovdje masovni pokolj pripisuje proroku Iliji, neki autori smatraju da se zapravo radilo o političko-religijskoj čistki. ${ }^{47}$ Unutar starozavjetnog režima istine djelovanje proroka Elišeja prikazuje se u kontekstu borbe protiv kanaanskog kulta te vraćanja vjere u Jahvu kao jedinog i pravog Boga. Elišej je prikazan kao nasljednik proroka Ilije i čudotvorac koji svojim djelovanjem utvrđuje jahvistički kult. ${ }^{48}$ Gotovo stoljeće kasnije starozavjetni režim istine kroz djelovanje proroka Amosa aktualizira sukob s kanaanskim kultom te kritizira sakralnu prostituciju koja se prakticira u hramu u Betelu. ${ }^{49}$ Glavni je grijeh za Amosa otpad od prave vjere i prihvaćanje Baala. ${ }^{50}$ I u djelovanju proroka Izaije vidimo pokušaje režima istine da pročisti jahvistički kult, gdje se kritika usmjerava na čin sakralne prostitucije koji se prakticira ispod svetog drveća. ${ }^{51}$ Tako čitamo:

»Da, stidjet ćete se zbog hrastova što ih sad obožavate i crvenjet ćete zbog gajeva u kojima sad uživate.« (Iz 1,29)

Drvo kao simbol kanaanskog kulta prikazuje režim u negativnom kontekstu. U tekstovima u knjizi proroka Izaije koji se pripisuju nepoznatom proroku nazvanom Tritoizaija, a koji nastaju nekoliko stoljeća nakon tekstova s početka knjige i možemo ih smjestiti u 5. stoljeće prije nove ere, sukob s kanaanskim kultom plodnosti i dalje je aktualan. Režim istine kroz riječi proroka Izaije kritizira svećenstvo koje obavlja sakralnu prostituciju. ${ }^{52}$

Narativ o iskonskom grijehu starozavjetni režim istine prikazuje kao izvor svega zla. On je odgovor na pitanje odakle potječe zlo. Upravo se u toj činjenici očituje vrhunac antagonizma prema kanaanskom kultu. Režim istine postavlja subjekte u poziciju u kojoj je jedina alternativa pravom i istinskom Bogu prihvaćanje zla i vječna osuda. Kanaanski kult zauzima mjesto iskonskog protivnika Boga i prikazan je kao moment stvaranja grijeha kao takvog. Režim istine to postiže fokusirajući se na tri ključne odrednice kanaanskog kulta: prva je simbol zmije kao falusno utjelovljenje boga Baala, druga je drvo spoznaje kao centralno mjesto Baalova kulta, a treća seksualni odnos kao takav, koji u sakralnoj prostituciji kanaanskog kulta zauzima važno mjesto te sada postaje čin grijeha.

Zmija zauzima važnu ulogu u narativu o iskonskom grijehu. Zmija je ta koja ženu uči grijehu, a kada govori ženi, boga naziva Elohim..$^{53}$ Ovdje starozavjetni režim istine ispušta ime za Boga koje se koristi u redcima prije toga, odnosno umjesto imena Jahve koristi se ime Elohim jer postoji potreba da se naglasi grešnost zmije. Naime, Elohim je izraz za Boga koji koriste grešnici, dok je termin Jahve rezerviran za Izraelce kao sveta riječ te ju grešan čovjek ne smije izgovoriti. ${ }^{54}$ Upravo u prikazu zmije možemo vidjeti izvorište moći koje utječe na formiranje starozavjetnog režima istine. Tu treba imati na umu da simbol zmije nije iskorišten slučajno, već je ona vanjski element koji u starozavjetnom režimu istine može zauzimati samo negativnu ulogu. Knjiga Postanka opisuje trenutak kušnje zmije sljedećim tekstom:

»Zmija bijaše lukavija od sve zvjeradi što je stvori Jahve, Bog. Ona reče ženi: 'Zar vam je Bog rekao da ne smijete jesti ni s jednog drveta u vrtu?' Žena odgovori zmiji: 'Plodove sa stabala u vrtu smijemo jesti. Samo za plod stabla što je nasred vrta rekao je Bog: 'Da ga niste jeli! I ne dirajte u nj, da ne umrete!' Nato će zmija ženi: 'Ne, nećete umrijeti! Nego, zna Bog: onog dana 
kad budete s njega jeli, otvorit će vam se oči, i vi ćete biti kao bogovi koji razlučuju dobro i zlo.' Vidje žena da je stablo dobro za jelo, za oči zamamljivo, a za mudrost poželjno: ubere ploda njegova i pojede. Dade i svom mužu, koji bijaše s njom, pa je i on jeo. Tada se obadvoma otvore oči i upoznaju da su goli. Spletu smokova lišća i naprave sebi pregače.« (Post 3,1-7)

Negativan kontekst koji se pridaje zmiji otkriva dinamički proces formiranja režima istine. Treba imati na umu da u kanaanskom kultu sakralne prostitucije zmija zauzima ključno mjesto. Ona je simbol boga Baala, točnije predstavlja muški spolni organ samog božanstva. ${ }^{55}$ Falusni simbol u obliku zmije bio je postavljen na raskršćima te često pod svetim drvetom, gdje bi onda Kanaanci i Izraelci prakticirali sakralnu prostituciju. ${ }^{56}$ Postojalo je vjerovanje da će činom spolnog sjedinjenja postići sličnost s božanstvom. ${ }^{57}$ Pojedinac tako postaje kao Baal. Ovdje možemo zamijetiti da postoje tri elementa koja egzistiraju izvan starozavjetnog režima istine: zmija kao falusni simbol boga Baala; svetost drveta ispod kojeg se vrši sakralna prostitucija; te vjerovanje da nakon izvršenog čina subjekt postaje sličan bogu. Starozavjetni režim istine tako treba utemeljiti koncept iskonskog grijeha da istisne istine prijašnjih režima.

Upravo se u tom dinamičkom procesu, gdje kanaanski kult zauzima negativno mjesto, formira nova istina koja će zauzeti središnje mjesto u starozavjetnom režimu istine, a kasnije i kršćanskom režimu, koji će nastaviti proizvoditi znanje o iskonskom grijehu. Za subjekte starozavjetnog režima prihvaćanje istina kanaanskog kulta može značiti samo otpad i isključenje.

U narativu o iskonskom grijehu možemo zamijetiti strukture moći koje su direktan produkt fetišizacije seksualnosti. Za drvo spoznaje koristi se glagol jada, ${ }^{58}$ koji se u isto vrijeme upotrebljava za seksualni čin. Starozavjetni režim istine prispodobom u kojoj muškarac i žena jedu s drveta spoznaje zapravo želi naglasiti seksualni čin kojem nije svrha prokreacija, a svojstven je Baalovu kultu. Seksualni čin kojem nije svrha prokreacija time se želi ukloniti kao dopušteno ponašanje unutar starozavjetnog režima istine. Time se formira fiksacija na tu vrstu spolnog čina, koju će kasnije preuzeti kršćanski režim istine te koja u njemu i danas zauzima značajno mjesto. Na ovom primjeru možemo zamijetiti dinamički proces formiranja režima istine kada znanje koje postoji u raznim izvorima moći modificira sam režim koji onda proizvodi »jednu « istinu.

U navedenom uočavamo dinamički proces formiranja istine. Istina nije vječna i nepromijenjena, ona je dinamički oblikovana raznim razmještajima moći. Na primjeru istine o seksualnom činu kojemu nije svrha prokreacija, a koja i u suvremenoj formaciji kršćanskog režima istine zauzima važno mjesto, za-

47

Usp. A. Rebić, Prorok i njegova preljubnica, str. 45.

48

Usp. A. Rebić, Prorok čovjek Božji, str. 40-43.

49

Usp. Adalbert Rebić, Amos - prorok pravde, Kršćanska Sadašnjost, Zagreb 1993., str. 42.

50

Usp. A. Rebić, Prorok čovjek Božji, str. 46.

51

Usp. A. Rebić, Jeruzalemska Biblija, str. 1072. 52

Usp. A. Rebić, Prorok čovjek Božji, str. 62.
53

Usp. ibid., str. 135.

54 Usp. ibid.

55

Usp. ibid., str. 140.

56

Usp. ibid.

57

Usp. ibid.

58

Usp. ibid., str. 139. 
mjećujemo dinamički proces oblikovanja istine radi potrebe za istiskivanjem istina proizvedenih oko vjerovanja vezanih uz Baalov kult. Seksualni čin kojem nije svrha prokreacija tako postaje nepoželjan jer je proizvod Baalova kulta. Istina o seksu ne formira se iz jednog monolitnog izvora. Ona je modelirana zbog potrebe za istiskivanjem režima koji ugrožavaju starozavjetni režim istine. Tako je znanje o seksu kojemu nije svrha prokreacija dinamički proizvedeno i ugrađeno u temelje prvo starozavjetnog, a potom i kršćanskog režima istine.

Na temelju proizvedenog znanja o iskonskom grijehu kršćanski režim istine definira čovjeka kao iskvareno biće. Iako je odgovornost svakog pojedinca umanjena zbog činjenice da je iskonski grijeh počinio prvi čovjek - Adam ili čovjek zemlje proizveden od praha zemaljskog - svaki subjekt nosi djelomičnu odgovornost za taj iskonski grijeh počinjen prije njegova rođenja. Nesavršenost subjekta ispravlja se kada on postaje subjekt kršćanskog režima istine. Motivacija kršćanskog režima istine za konstantnu proizvodnju znanja o padu prvog čovjeka i sveg čovječanstva nalazi se u opravdanju nužnosti prihvaćanja tog znanja kao apsolutne oslobađajuće istine. Da nije bilo pada, ne bi bilo ni kršćanstva. Dokidanje prokletstva iskonskog grijeha u samom je središtu kršćanskog režima istine, u događaju otkupljenja Isusa Krista. Ali ipak, ono se ne događa samo po sebi jer je pritom nužno prihvaćanje istina samog režima. Ako subjekt ne prihvaća znanje koje proizvodi režim, vraća se u stanje prokletstva.

\section{Druga žarišna točka seksualne formacije moći}

Kao što smo već naveli, druga žarišna točka formirana je oko utjecaja antičke misli na seksualnu formaciju moći kršćanskog režima istine. Poseban utjecaj na proces formiranja kršćanskog režima istine ostavlja stoička filozofija. Budući da se u svojoj analizi usredotočujemo na seksualnu formaciju moći, nužno je istaknuti da je utjecaj antičke filozofije bio značajan. Zamjetno je poistovjećivanje kršćanstva sa filozofijom, što Hadot ispravno uočava.

Ovo poistovjećenje kršćanstva s istinskom filozofijom nadahnut će mnoge vidove Origenova naučavanja i ostati živo u svem origenizmu, posebno kod kapadokijskih otaca: Bazilija iz Cezareje, Grgura Nazijanskog, Grgura iz Nise, i jednako tako kod Ivana Zlatoustog. Oni govore o »našoj filozofiji «, o »cjelovitoj filozofiji« ili »filozofiji po Kristu«. Možda ćemo se upitati je li takvo poistovjećenje bilo legitimno i nije li ono tako snažno doprinijelo čuvenoj »helenizaciji « kršćanstva o kojoj se često govorilo. ${ }^{59}$

Isto tako treba istaknuti da Origen preuzima praksu ispita savjesti od pitagorejaca, epikurejaca i stoika, koja ulazi u monašku praksu, a preporučuju je i sveti Ivan Zlatousti, Dorotej iz Gaze, Atanazije i drugi. ${ }^{60}$ Po pitanju postizanja duhovnog savršenstva zamjetan je i utjecaj neoplatonizma preuzimanjem koncepta apatheiae, potpunog izostanka strasti. ${ }^{61}$ Nadalje je važno istaknuti i preuzimanje koncepta vježbanja umiranja u platonovskom smislu, a zamjećujemo ga kod Klementa Aleksandrijskog, Grgura Nazijanskog i Maksima Ispovjednika. ${ }^{62}$ Foucault nastavlja u istom tonu te ističe da se uočava značajan utjecaj antičke filozofije na kršćansko monaštvo. ${ }^{63}$

U kontekstu utjecaja antičke filozofije na seksualnu formaciju moći treba istaknuti Seneku, koji naučava da se ništa ne treba činiti radi užitka, a mudar suprug u ljubavi prema svojoj ženi dopušta da ga vodi razum, a ne emocije, ljubav stoga treba voditi samo radi potomstva. ${ }^{64}$ Tako se crkveni otac Jeronim 
u spisu protiv Joviniana poziva na stoičku filozofsku praksu te parafrazira Seneku:

»Sramotno je voljeti tuđu ženu, ili svoju previše. Mudrac će voljeti razumom, ne strašću. « ${ }^{65}$

Učitelj stoičke filozofije Musonije nadovezuje se na Seneku i svaki bračni seksualni čin koji ne vodi prokreaciji proglašava nemoralnim. ${ }^{66}$ Ta stoička formulacija nalazi plodno tlo u kršćanskom režimu istine te je uspješno asimilirana, a uočavamo ju i u suvremenom teološkom diskursu. Stoičko usmjeravanje procesa proizvodnje istine unutar kršćanskog režima istine imat će ogroman utjecaj na razvoj teologije i regulaciju seksualnog čina. Sveti Augustin, kako ćemo kasnije istaknuti, spaja nauk o istočnom grijehu - koji formaciju moći oblikuje u prvoj žarišnoj točki - sa seksualnom požudom i osjećajem užitka. Tako se od muškog subjekta zahtijeva da prilikom seksualnog odnosa prekine užitak, ali ne i sam čin. ${ }^{67}$ Regulacija seksualnog čina klasificira seks s lijepom ženom većim grijehom - jer je u njemu i užitak veći - nego seks s ružnom ženom, gdje je užitak manji. ${ }^{68}$ Stoički koncept izbjegavanja užitka u bilo kojem obliku u kršćanskom se režimu istine dodatno radikalizira u stavovima pape Leona Velikog i Fulgencija Ruspijskog, koji tvrde da je svaki bračni seksualni čin u svojoj biti grešan čin. Ipak, taj stav malo ublažava sveti Grgur Veliki, koji kaže da bračni čin nije grešan samo kada se čini s namjerom prokreacije. ${ }^{69} \mathrm{Na}$ tragu je tih stavova i sveti papa Ivan Pavao II., koji govoreći o seksualnom činu u braku ističe da je moguće učiniti preljub i s vlastitom suprugom ako muškarac seksu pristupa vođen požudom. ${ }^{70}$

Da bitan utjecaj na kršćanski režim istine ostavlja misao stoičke filozofije, vidimo i u često korištenoj metafori slona koja se koristi za model bračnih odnosa. Ona će zauzeti važno mjesto unutar režima istine prolazeći proces aktualizacije do 19. stoljeća, kada je u viziji pripisana Isusu Kristu. Autor je metafore stoik Plinije Stariji, koji da bi opisao bračne odnose navodi slona kao primjer bračne čistoće koju pronalazimo u prirodi. Plinije navodi da se slon pari uvijek u tajnosti, svake dvije godine, i to ne više od pet dana jer

59

Usp. Pierre Hadot, Duhovne vježbe i antička filozofija, preveo Zlatko Wurzberg, Sandorf, Mizantrop, Zagreb 2013., str. 62.

60

Usp. ibid., str. 70; te Michel Foucault, On the Government of the Living: Lectures at the Collège de France, 1979-1980, Palgrave Macmillan, London 2014., str. 245-246.

61

Usp. P. Hadot, Duhovne vježbe i antička filozofija, str. 71

62

Usp. ibid., str. 74.

63

Usp. M. Foucault, On the Government of the Living, str. 274

64

Usp. Uta Ranke-Heinemann, Eunuchs for the Kingdom of Heaven, Doubleday, New York 1990., str. 12
65

Saint Jerome, »Against Jovinianus (Book I)«, prema: Philip Schaff, Henry Wace (ur.): Nicene and Post-Nicene Fathers, Second Series, sv. 6, preveli W. H. Fremantle, G. Lewis, W. G. Martley, Christian Literature Publishing Co., Buffalo 1893. Dostupno na: http://www. newadvent.org/fathers/30091.htm (pristupljeno: 10. 3.2019.)

66

Usp. U. Ranke-Heinemann, Eunuchs for the Kingdom of Heaven, str. 12.

67

Usp. ibid., str. 77.

68

Usp. ibid., str. 159.

69

Usp. ibid., str. 136-137.

70

Garry Wills, Papinski grijeh: strukture obmane, preveo Igor Kusin, Naklada Jesenski i Turk, Zagreb 2015., str. 122. 
šestog dana ide na rijeku, gdje se opere i tek se onda vraća u krdo. ${ }^{71}$ Ta se stoička metafora nalazi u djelima raznih kršćanskih autora, pa ju tako Richard iz St. Victora, Alain de Lille, Codex latinus Monacensis, dominikanac William Peraldus, sveti Franjo Saleški i blažena Ana Katarina Emerih koriste da bi opisali bračne odnose. ${ }^{72}$ Franjo Saleški navodi:

»On nikada ne mijenja svoju družicu i nježno voli onu koju je izabrao, sa kojom se pari jednom u tri godine, i to samo pet dana, to čini u potaji da ga ne bi tko zamijetio. Šesti dan izlazi iz potaje, odlazi direktno do rijeke, gdje pere cijelo svoje tijelo, u krdo se ne vraća dok ne bude potpuno čist. Nije li to dobra i poštena priroda? ${ }^{73}$

Analizirajući tu metaforu, Foucault pronalazi i njezine druge kršćanske upotrebe, koje se proširuju u Physiologusu, kršćanskom tekstu iz 4. stoljeća na koji se referiraju mnogi kršćanski autori, gdje se navodi da se slon prilikom seksualnog čina okreće prema istoku, gdje je lokacija rajskog vrta. ${ }^{74}$ Ipak, ova stoička metafora najsnažnije preuzima kršćanski identitet kada se pripisuje Isusu Kristu. Tako stigmata blažena Ana Katarina Emerih, koja prima poruke od Isusa Krista u obliku vizija, navodi da je u jednoj takvoj viziji vidjela Isusa Krista na svadbi u Kani gdje je držao govor mladencima o bračnoj čistoći i navodio metaforu slona kao primjer čistoće u braku. ${ }^{75}$

Drugi bitan moment koji treba zamijetiti unutar žarišne točke koja se formira oko utjecaja antike na kršćanski režim istine kroz seksualnu formaciju moći jest apsorbiranje koncepta djevičanstva u smislu uzdržavanja od seksa radi otvaranja kanalima božanskog utjecaja. Tu ponajprije treba imati na umu kult božice Veste. ${ }^{76}$ Djevojke koje bi postale svećenice bile su obvezane, dok god prakticiraju tu službu, na strogo uzdržavanje od seksualnih odnosa. Nakon prestanka službe, a ne prije navršenih 30 godina, mogle su se udati i imati djecu. ${ }^{77}$ Upravo ovdje uočavamo strogu razdjelnicu između svetog i profanog: žena koja je postala svećenicom morala je proći određenu transformaciju da bi otvorila komunikaciju prema božanskom. Slično uočavamo i kod Filona Aleksandrijskog, koji navodi da je Mojsije nakon susreta s Bogom na Sinaju bio transformiran i prestao je prakticirati seksualne odnose. ${ }^{78}$ Kršćanskom režimu - koji od starozavjetnog preuzima, sada već prilično ukorijenjenu odbojnost prema seksualnom činu - nije problem prihvatiti koncept djevičanstva kao kanala božanske inspiracije jer je njegova suprotnost odlika kanaanskog kulta plodnosti.

Ovdje nastupa treći ključan moment utjecaja antike na kršćanski režim istine, a utjelovljuje se u antičkom uvjerenju da je seksualni čin štetan za čovjekovo zdravlje. Ova štetnost očituje se u gubitku energije koji pojedinac osjeća nakon izvršenog čina. O štetnome utjecaju govore Pitagora, Ksenofan, Platon, Aristotel, a Hipokrat piše o mladiću kojega je pretjerana seksualna aktivnost odvela u ludilo, dok Soran iz Efeza nabraja razne štetne utjecaje. ${ }^{79} \mathrm{U}$ trenutku rane formacije kršćanskog režima istine možemo zamijetiti utjecaj medicinskih spoznaja antike, a pritom se u kršćanski diskurs štetnosti seksualnog čina dodaje i koncept grijeha. Tako se Toma Akvinski, naglašavajući grešnost seksualnog čina, nadovezuje na Aristotelovu tvrdnju da seksualno zadovoljstvo remeti proces promišljanja i ističe da seksualni čin uništava razum. ${ }^{80}$ Albert Veliki tvrdi da seksualni čin uništava mozak i oči uzrokujući njihovo isušivanje, što dovodi do toga da mozak smanjuje svoje dimenzije i postaje veličine nara ${ }^{81}$ Naučavanje Plinija starijeg da su djeca začeta za vrijeme mjesečnice rođena bolesna, zagnojene krvi ili mrtva rezultirao je proizvodnjom cijelog raspona duhovno-tjelesnih poremećaja s ciljem klasificiranja te vrste seksualnog odnosa kao nedopuštenog. Tako su za kršćanski režim istine tako začeta djeca gubava, epileptična, glupa, imaju iskrivljene noge, hidro-cefalič- 
nu glavu i opsjednuta su đavlom..$^{82}$ Da bi se subjekte režima istine spriječilo u prakticiranju nedopuštenih seksualnih odnosa, bilo je nužno proizvesti znanje koje nije poduprto činjenicama, ali je neovisno o tome dodavalo dodatne argumente tezi o grešnosti nedopuštenog seksualnog odnosa.

\section{Treća žarišna točka seksualne formacije moći}

Treća žarišna točka seksualne formacije moći oblikuje se unutar režima koji je već nastao i ima uspostavljene mehanizme proizvodnje istine. U ovoj žarišnoj točki zamjećujemo pet mehanizama koji proizvode znanje o seksu.

Zabrana se usredotočuje na dopuštenost ili nedopuštenost samog čina ili raznih elemenata vezanih uz čin. Zabrane su usmjerene u apsolutnom i relativnom smislu. Apsolutne zabrane odnose se na sve seksualne odnose koji nisu između bračnih drugova. Relativne su zabrane one u kojima se supružnicima - iako je seksualni odnos među njima dozvoljen - ne dopušta da ga prakticiraju na bilo koji način osim onoga koji je strogo propisan. Režim istine zabranu stavlja na osjećaj užitka koji subjekt proživljava prilikom samog čina. Ta se zabrana temelji na nauku svetog Augustina u kojemu se osjećaj užitka spaja s naukom o istočnom grijehu. Tako subjekt smije prakticirati sam čin, ali pritom otklanjajući osjećaj ugode u požudi, uz dodatnu zabranu prekida seksualnog čina. Prekid samog čina značio bi uklanjanje prokreativne dimenzije. Ovdje je nužno spomenuti Foucaultovo nedavno objavljeno djelo Priznanja puti. Iako je kod drugih kršćanskih autora prisutno svođenje seksualnog čina na prokreaciju, Foucault smatra da u Augustinovu slučaju to nije izričito tako. ${ }^{83}$ Augustin tako u braku dopušta seksualni čin radi prokreacije i radi izbjegavanja počinjenja većega grijeha u kontekstu izbjegavanja požude. ${ }^{84}$ Užitak koji se javlja prilikom seksualnog čina ne mora biti plod požude ako se čin obavlja ispravno. ${ }^{85}$ Foucault ističe da Augustin pojašnjava ovaj stav tako da ne rela-

71

Usp. U. Ranke-Heinemann, Eunuchs for the Kingdom of Heaven, str. 14.

\section{2}

Usp. ibid., str. 13; isto zamjećuje i Foucault navodeći da je ta metafora preuzeta od Plinija i da je ušla u kršćansku tradiciju kao primjer bračne čistoće. Usp. Michel Foucault, Povijest seksualnosti 2: upotreba zadovoljstava, preveo Zlatko Wurzberg, Domino, Zagreb 2013., str. 21-22.

73

U. Ranke-Heinemann, Eunuchs for the Kingdom of Heaven, str. 14.

74

Usp. Michel Foucault, Subjectivity and Truth: Lectures at the Collège de France 1980-1981, Palgrave Macmillan, London 2017., str. 5.

75

Usp. U. Ranke-Heinemann, Eunuchs for the Kingdom of Heaven, str. 14.

76

Usp. M. Foucault, Subjectivity and Truth, str. 149.

\section{7}

Usp. Peter Brown, The Body and Society: Men, Women and Sexual Renunciation in Early Christianity, Faber and Faber, London 1991., str. 8-9.

78

Usp. ibid., str. 67.

79

Usp. U. Ranke-Heinemann, Eunuchs for the Kingdom of Heaven, str. 10.

80

Usp. ibid., str. 191-192.

81

Usp. ibid., str. 182.

82

Usp. ibid., str. 22.

83

Usp. Michel Foucault, Les aveux de la chair, Gallimard, Pariz 2018., str. 367.

84

Usp. ibid., str. 369.

85

Usp. ibid., str. 373. 
tivizira upotrebu požude u braku, nego iznosi da ako se čin obavlja ispravno, onda se ne radi o požudi. ${ }^{86}$ Dva su važna elementa seksualnog čina koja ga čine grijehom: požuda i prekomjernost. ${ }^{87}$ Ipak, požuda je nužna posljedica čovjekova pada i stoga uvijek prisutna u samom činu, ali ako je pod kontrolom volje onoga tko prakticira seksualni čin u braku, može osloboditi grešnosti. ${ }^{88}$ Režim istine kasnijim teološkim razvojem zabranjuje čin supružnika kojemu nije svrha prokreacija. Druge relativne zabrane obuhvaćaju primjerice zabranu bračnog čina za vrijeme mjesečnice, pri čemu se snaga zabrane pojačava strahom od tjelesno-duhovnih deformacija začetog djeteta.

Određivanje krivice za prijestupe protiv normi režima istine bilo je nužno definirati kroz mnogostruke klasifikacije samih prijestupa. Jedna od važnijih klasifikacija - koja je usmjeravala razvoj teologije u periodu skolastike i kasnije - ona je u kojoj se prijestupi dijele na grijehe počinjene u odnosu na prirodni zakon. Glavna je točka vrednovanja pitanje vodi li seksualni čin prokreaciji ili ne. Režim istine grijehe koji su u skladu s prirodnim zakonom naziva peccata secundum naturam ${ }^{89}$ i u njih se ubraja preljub, bludničenje, incest, silovanje, otmica. Druga je kategorija težih grijeha, onih protivnih prirodnom zakonu, zbog čega se nazivaju peccata contra naturam, ${ }^{90}$ a ta kategorija objedinjuje masturbaciju, homoseksualnost, sodomiju i bestijalnost. Tako za kršćanski režim istine supružnici koji prekinu seksualni odnos s ciljem sprečavanja začeća čine teži grijeh nego što je čin silovanja majke, s obzirom na to da je potonji otvoren prokreaciji i vodi začeću. ${ }^{91}$ Kakve je konkretne posljedice imalo vrednovanje prokreacije u klasifikaciji seksualnih činova, najbolje zamjećujemo u propisanoj kazni za oralni seksualni odnos između supružnika. Za režim istine prakticiranje oralnog seksa u braku puno je teži prijestup nego počinjenje ubojstva, što zamjećujemo u činjenici da se za počinjenje grijeha ubojstva pokora prakticirala sedam godina, dok se oralni seks kažnjavao pokorom od 15 godina, a u nekim slučajevima i doživotno. ${ }^{92}$ Samozadovoljavanje je promatrano kao teži grijeh nego preljub u braku, jer samozadovoljavanje ne vodi prokreaciji. Tako Gracijanov dekret navodi:

»Više je sramotno kada to žena čini sebi nego kada njen suprug to čini nekoj drugoj ženi.« ${ }^{93}$

Devijacija od propisanog položaja prilikom seksualnog čina klasificirana je kao grijeh protiv prirode. Jedini je dopušteni položaj koji supružnici smiju zauzeti misionarski, odstupanje od njega u režimu je teži grijeh nego incest ili silovanje. ${ }^{94}$ Suvremene klasifikacije grijeha kršćanskog režima istine razlikuju smrtne i lake grijehe, gdje se počinjeni grijeh vrednuje prema svojoj težini. ${ }^{95} \mathrm{U}$ odnosu na nasljeđivanje razlikuju se istočni grijeh, koji je zajednički svim ljudima i s kojim se svatko rađa, i osobni grijeh, koji čini pojedinac. Daljnje klasifikacije kršćanskog režima istine idu u smjeru razlikovanja grijeha po vrsti. Pod time se najprije misli na vrijednosti, kreposti ili zapovijedi režima istine koje su povrijeđene. ${ }^{96}$

Ako promatramo klasifikaciju seksualnog čina u odnosu na prokreaciju, uočavamo da je ona u potpunosti androcentrično pozicionirana. Aktivni element prilikom procesa prokreacije u seksualnom činu kršćanski režim istine pripisuje muškarcu. Muškarac začinje dijete, a žena ga samo prima, ona je posuda u kojoj dijete raste. Ovdje je kršćanski režim istine pod utjecajem antičke filozofske misli. Najsnažnije teorijsko utemeljenje kršćanskog režima istine formira se u vrijeme skolastike kroz teologiju Tome Akvinskog, koji taj nauk preuzima od Aristotela. ${ }^{97}$

Prilikom reguliranja seksualnog čina, formacija moći kršćanskog režima istine značajnu pažnju stavlja na ono što se regulira, koji je položaj dopušteno 
zauzeti, vrijeme kada se čin smije obaviti i broj obavljenih činova. Kršćanski režim istine djelomično dopušta seksualni čin između muške i ženske osobe u crkvenom braku s ciljem stvaranja potomstva. Taj restriktivno-minimalistički pristup seksualnom odnosu proizlazi iz asimiliranog uvjerenja stoicizma, koji seksualni čin opravdava samo radi prokreacije. Foucault na toj liniji zaključuje:

»Kršćanstvo će mnogo toga preuzeti iz takve zamisli kada bude željelo izraditi etiku bračnog odnosa. $\ll^{98}$

Kršćanski režim istine ovo uvjerenje legitimizira prošivajući njegovo značenje božanskim označiteljem. Tako svi bračni odnosi postaju potencijalno grešni, što smo već istaknuli u prethodnim poglavljima, a to učenje posebno naglašavaju papa Leon Veliki i Fulgencije Ruspijski. Papa Grgur Veliki dopušta izuzetak radi prokreacije. Za kršćanski režim istine seksualni je čin konstantan podsjetnik na gubitak besmrtnosti, ali u isto vrijeme i sredstvo da se taj gubitak nadoknadi. Ta je ideja posebno izražena u teološkom mišljenju patrističkog razdoblja. ${ }^{99}$ Iz tog razloga regulacija režima istine penalizira sve ono što odstupa od prokreacije. Seksualni je čin između bračnih partnera dopušten, ali kao što smo već istaknuli, užitak u požudi prilikom čina nije dopušten ako nije kontroliran voljom. Augustin osjećaj užitka prilikom seksualnog čina, ako je vođen požudom, povezuje s iskonskim grijehom. Slično zamjećuje i Foucault u analizi ovog Augustinova nauka te navodi:

»Tu se seksualna aktivnost svojim oblikom i svojim učincima veže uz zlo, ali sama po sebi i u suštini nije zlo. Svoje prirodno i racionalno ostvarenje nalazi u braku; ali, osim izuzetno, brak nije formalni i neophodni uvjet da ona prestane biti zlo. «100

86

Usp. ibid.

87

Usp. ibid., str. 334.

88

Usp. ibid., str. 359.

89

Usp. Petar Šolić, »Teologija homoseksualnosti«, Obnovljeni život 45 (1990) 1-2, str. 44-77, str. 51.

90

Usp. ibid.

91

Ovo tumačenje ulazi u zbirku kanonskog prava iz 12. stoljeća nazvanu Gracijanov dekret te je dio skupa zakona koji su na snazi u Katoličkoj crkvi do 1917. godine. Usp. U. Ranke-Heinemann, Eunuchs for the Kingdom of Heaven, str. 204. Drugi primjer vidimo u stavu Svetog Petra Lombardijskog, koji za one supružnike koji prakticiraju kontracepciju ističe: »Ona je kurva svome suprugu, a on čini preljub sa svojom ženom.« - Ibid., str. 205.

92

Iako su postojale varijacije u trajanju pokore, ona je uvijek bila dulja za oralni seks nego za ubojstvo. Usp. ibid., str. 149.
93

Ibid., str. 204.

94

Usp. ibid., str. 198.

95

Usp. Bernhard Häring, Kristov zakon, sv. 1, Opća kršćanska moralna teologija, preveli Ante Kusić et al., Kršćanska sadašnjost, Zagreb 1973., str. 340.

96

Usp. ibid., str. 353.

97

Usp. U. Ranke-Heinemann, Eunuchs for the Kingdom of Heaven, str. 186.

98

Michel Foucault, Povijest seksualnosti 3: briga o sebi, Domino, Zagreb 2013., str. 211.

99

Usp. P. Brown, The Body and Society, str. 86.

100

M. Foucault, Povijest seksualnosti 3, str. 231. 
Nadalje, nije dopušteno prekinuti seksualni čin da bi se spriječila trudnoća, a slična je regulacija na snazi i u suvremenosti, gdje zbog ne-zadovoljavanja kriterija prokreacije kršćanski režim istine osuđuje upotrebu kondoma kao oblika kontracepcije. Papa Pio XII. u prvoj polovici 20. stoljeća, regulirajući upotrebu kontracepcije prilikom seksualnog čina, ističe da korištenje nedopuštenih oblika kontracepcije rezultira direktnom osudom na pakao bez mogućnosti pomilovanja. ${ }^{101}$ Glavni razlog tako radikalnog stava treba tražiti u seksualnom činu koji spada u kategoriju protuprirodnih grijeha koji ne dovode do prokreacije. Kršćanski režim istine dopušta one oblike kontracepcije u kojima prokreacija nije spriječena. Tako se subjektima savjetuje korištenje metode ritma, prilikom koje se vodi računa o plodnim i neplodnim danima. ${ }^{102}$ Reguliran je i položaj koji subjekt mora zauzeti i spolno je određen: muškarac mora zauzeti poziciju gdje se on nalazi gore kao aktivni sudionik seksualnog čina, dok žena, koja ima pasivnu ulogu mora biti ispod muškarca. Bilo kakav drugi položaj osim misionarskog položaja nije dopušten i klasificiran je kao protuprirodni grijeh te se izjednačava s ubojstvom. ${ }^{103}$ Seksualni čin mora se prakticirati u mraku jer je muškarcu zabranjeno gledati golo tijelo partnerice. ${ }^{104}$ Režim istine definira i vrijeme kada se seksualni čin smije obavljati. Sveti Augustin tako traži da se seksualni čin ne prakticira u dane molitve i pokore, nedjeljom i u vrijeme korizme, dok sveti Jeronim i Origen govore da se seksualni čin treba izbjegavati na dane pričesti. ${ }^{105}$ Albert Veliki nadovezuje se i pojašnjava da to nikako ne smije biti u vrijeme blagdana. ${ }^{106}$ Kvantiteta seksualnog odnosa isto je tako regulirana, kršćanski režim istine traži da se seksualni čin ne obavlja često, jer njegovo prakticiranje vodi u smrt. Tako Albert Veliki navodi:

»Psi često prate one koji su imali učestale seksualne odnose. Psi vole smrad raspadajućih leševa, pa tako prepoznaju osobu koja je često prakticirala seksualni čin, jer se ona približava stanju leša zbog sjemena koje u njoj trune. ${ }^{107}$

Kršćanski režim istine kažnjava nedopušteno seksualno ponašanje te određuje primjerenu kaznu kao zadovoljštinu za učinjeni grijeh. Tarife koje se određuje za počinjene grijehe variraju i nisu u svakom razdoblju ili području iste. Upravo u tim varijacijama možemo uočiti fluidnost dinamičke proizvodnje znanja o grešnom seksualnom ponašanju unutar režima istine. Tako Teodorov penitencijar za one koji napuste svoju suprugu i ožene se za drugu propisuje pokoru i kušnju od 7 godina ili, u lakšoj varijanti, samo pokoru od 15 godina. ${ }^{108}$ Kazne su lakše ako je duhovna šteta manja, tako da ako počinitelj nije u braku, a učini preljub ili silovanje susjedove žene, onda će u razdoblju od tri godine imati tri posta po četrdeset dana. ${ }^{109}$ Kazna je za oskvrnuće djevice pokora koja uključuje uskratu mesa, vina i medovine, a ako je djevica položila redovničke zavjete, onda je kazna trostruko veća. ${ }^{110}$ Velški penitencijar iz 6. stoljeća s druge strane preljub gleda značajno rigoroznije. Seksualni čin s redovnicom, udanom ženom, zvijeri ili muškarcem izjednačen je u kontekstu kazne, počinitelj je do kraja svog života izbačen iz zajednice vjernika. ${ }^{111} \mathrm{Cu}$ meanov penitencijar donosi tarife za prijestupe u redovničkim zajednicama. Prijestupi vezani uz istospolne odnose tarifiraju se različito, gdje se uzima u obzir starost počinitelja i učestalost čina. Dječaci do dvadeset godina koji zajednički prakticiraju masturbaciju i priznaju grijeh prakticirati će pokoru dvadeset ili četrdeset dana prije uzimanja pričesti; ako ponavljaju čin nakon pokore, onda će dobiti novu pokoru od 100 dana, a ako se praksa nastavi, prakticirati ce pokoru godinu dana. ${ }^{112}$ Žrtva seksualnog iskorištavanja kažnjava se kao i počinitelj, ali pokora je duplo manja. Dječak do deset godina kojeg je iskoristio stariji dječak, postit će tjedan dana, a ako je pristao na čin, onda dvadeset dana. ${ }^{113}$ 
U skladu s već navedenom odlikom fluidnosti dinamičke proizvodnje istine kršćanskog režima možemo zamijetiti korekcije nauka koje se nameću kao nužnost zbog utjecaja vanjskih čimbenika. Na primjeru pokorničke prakse uočavamo da se događa nekoliko pomaka nauka. Pomak od javne ispovijedi svojstvene vremenu kršćana antike, do privatne, koja se formira pod utjecajem redovnika ispovjednika u ranom srednjem vijeku. Drugi drastični pomak očituje se u drastičnom ublažavanju pokore koji se događa u suvremenosti. Ponovna integracija subjekata koji su učinili prijestup protiv kršćanskog režima istine bila je dvojaka: lakše je prijestupe bilo dovoljno javno i grupno priznati te su oni bili oprošteni, međutim prijestupi koji se karakteriziraju kao teži, trebali su biti iskupljeni kroz proces javne pokore pred zajednicom uz javno priznanje grijeha. Ponekad iskupljenje nije bilo moguće te se osoba trajno isključivala iz zajednice. ${ }^{114}$ Korekciju nauka oko pokorničke prakse zamjećujemo u ranom srednjem vijeku u pojavi monaha ispovjednika koji misionarski djeluju na području Irske. Počinju se stvarati zbirke pokorničkih knjiga u kojima se donosi popis grijeha i radnji potrebnih da bi se ti grijesi ispravili. Proces priznanja grijeha i izricanja pokora više se ne prakticira pred cijelom zajednicom, nego pred svećenikom privatno. ${ }^{115}$ Proces iskupljenja i ponovne integracije u kršćansku zajednicu nije bio lak i često je trajao godinama dok cijela pokora ne bi bila izvršena. Potrebna je bila izjava subjekta da je modificirao ponašanje i da neće prakticirati grešnu radnju te je bilo potrebno obavljanje molitve ili nekog simboličkog čina pokore. Dok pokora u srednjem vijeku može trajati godinama, u suvremenim formacijama kršćanskog režima istine ona se smanjuje na minute.

Drugi pomak nauka kršćanskog režima istine u kontekstu seksualne formacije moći zamjećujemo u vrednovanju grijeha samozadovoljavanja. Prakticiranje tog čina ulazilo je u težu kategoriju grijeha jer je kršilo imperativ prokreacije te se takav grijeh vrednovao kao protuprirodni čin. Posljedica je toga bila da se taj čin klasificira kao teži grijeh nego incest ili silovanje, a izjednačen je s ubojstvom. Da bi se kršćanska mladež zaštitila, provodile su se mjere sa-

101

Usp. G. Wills, Papinski grijeh, str. 122.

102

Ibid.

103

Ovakvo tumačenje kršćanski režim istine proizvodi unutar skolastičke teologije 13. stoljeća. U iznimnim slučajevima bilo je dopušteno koristiti i druge položaje ako je bilo nemoguće u misionarskom položaju ostvariti prokreaciju. Usp. U. Ranke-Heinemann, Eunuchs for the Kingdom of Heaven, str. 163.

104

Teodorov Penitencijar iz 7. stoljeća propisuje odredbu koja zabranjuje suprugu da vidi golo tijelo svoje supruge. Usp. John Thomas McNeill, Helena Margaret Gamer, Medieval Handbooks of Penance, Columbia U. P., New York 1991., str. 211.

105

Usp. U. Ranke-Heinemann, Eunuchs for the Kingdom of Heaven, str. 98.

106

Usp. ibid., str. 181.
107

Ibid., str. 182.

108

Usp. J. T. McNeill, H. M. Gamer, Medieval Handbooks of Penance, str. 195.

109

Usp. ibid.

110

Usp. ibid.

111

Usp. ibid., str. 173.

112

Usp. ibid., str. 113.

113

Usp. ibid.

114

Usp. ibid., str. 4-5.

115

Usp. ibid., str. 28. 
kaćenja reproduktivnih organa s ciljem izazivanje neugode i odvraćanja od stanja seksualne uzbuđenosti koja bi dovodila do čina masturbacije. Dječacima se provlačila žica kroz kožicu penisa, a djevojkama se provodila klitoridektomija spaljivanjem. ${ }^{116}$ Pod utjecajem razvoja suvremene medicine, koja masturbaciju ne promatra kao čin štetan za zdravlje ili nešto nesvojstveno procesu sazrijevanja, kršćanski režim istine u značajnoj mjeri korigira nauk te masturbacija od čina koji je gori od silovanja ili incesta ulazi u područje lakih grijeha. Taj grijeh za kršćanski režim istine više nije težak, a u nekim situacijama postaje spolno neuredan čin. Prilikom određivanja kazne za učinjen grijeh uzima se u obzir dob počinitelja, moralna zrelost te razni psihološki čimbenici. ${ }^{117}$

Bitan pomak zamjećuje se i u odnosu kršćanskog režima istine prema osjećaju užitka prilikom seksualnog odnosa. Kršćanski režim istine pod utjecajem teološkog promišljanja Augustina, koji spaja osjećaj užitka s naukom o istočnom grijehu, traži izbjegavanje tog osjećaja kao požude prilikom bračnog čina. Svaki je osjećaj požude jednako nedopušten jer je glavna svrha seksualnog odnosa prokreacija. Seksualni je čin za režim istine nužno zlo, u isto vrijeme podsjećanje na iskonski grijeh i gubitak besmrtnosti, ali i način da se besmrtnost nadiđe kroz proces reprodukcije. ${ }^{118}$ Međutim, kršćanski režim istine u suvremenosti korigira taj rigorozan pristup. Spolna požuda i užitak u braku dopušteni su pod uvjetom da su osobe prožete duhovnom i nadnaravnom ljubavlju, a ponašanje na spolnom području uređeno je prema Božjem zakonu. ${ }^{119}$ Prema tome, svrha kršćanskog braka nije isključivo prakticiranje prokreacije, a seksualni odnos izričito zlo. Ostavlja se mogućnost da se ljubav prenosi kroz bračni čin neovisno o začetku djeteta. Ipak, svjesno odbacivanje prokreacije i korištenje kontracepcijskih metoda koje se protive rađanju unutar režima istine se ne dopušta ni u suvremenosti.

\section{Zaključak}

U skladu s navedenim vidimo da se seksualna formacija moći kršćanskog režima istine fokusira na tri žarišne točke, koje se oblikuju oko ideološkog sukoba s kanaanskim kultom, na utjecaju antike i mehanizmima kontrole. Djelovanje ove formacije moći u potpunosti formira režim istine, što uočavamo u njegovoj strukturi. To ponajprije zamjećujemo u starozavjetnom režimu istine, koji kao posljedicu sukoba s kanaanskim kultom proizvodi narativ o padu, koji će biti glavni izvor nauka o istočnom grijehu i egzistencijalni element kršćanstva. Egzistencijalnost se očituje u procesu krštenja kao inicijaciji subjekata u zajednicu kršćana, gdje je krštenje čin oslobađanja od posljedica istočnog grijeha. Tri središnja elementa narativa - drvo spoznaje dobra i zla kao aluzija na sveto drveće kanaanskog kulta, zmija kao simboličko falusno utjelovljenje boga Baala te simbolika seksa kroz upotrebu glagola koji u isto vrijeme označava spoznaju i seksualni odnos - pozicioniraju seksualni čin u samo središte izvora zla. Ideološki rat između dvaju kultova jahvističkog i kanaanskog, tako postavlja temelje negativne klasifikacije seksualnog čina, koja je aktualna i u suvremenim manifestacijama kršćanskog režima istine. Osim toga, uočavamo i značajan utjecaj stoičke filozofije na koncept grijeha, osobito na isticanju isključivo prokreativne dimenzije seksualnog čina, koja postaje modelom kršćanskog odnosa. Seksualna formacija moći u ovome segmentu značajno modelira kršćanski režim istine te seksualni čin koji odstupa od prokreativne svrhe postaje teži grijeh od incesta ili se stavlja na istu razinu s ubojstvom. Režim istine regulira položaj, vrijeme, način i kvantitetu seksual- 
nog čina, klasificira njegove vrste i zabranjuje ih. Pomaci nauka razotkrivaju fluidnost proizvedenih istina što ukazuje na dinamičku narav režima istine, gdje ona nije proizvedena iz jednog centra, već se radi o složenoj mreži odnosa moći. Mehanizmi kontrole režima uvijek su vrednovani androcentrično, pa tako uočavamo da je za muškarca prilikom bračnog čina uvijek rezerviran gornji položaj, jer je on aktivni sudionik samog čina te prenositelj i stvaratelj života. Premda kršćanski režim istine dodaje božanski označitelj istinama proizvedenim unutar diskursa formiranog oko seksualnosti, utjecaji drugih režima istine, mehanizmi kontrole i androcentrično pozicioniranje ostavljaju snažan trag antropomorfne uvjetovanosti seksualne formacije moći koja oblikuje kršćanski režim istine.

\title{
Žarko Ament
}

\section{Vertical Structures of the Christian Regime of Truth}

\begin{abstract}
This paper analyses the formation of power of the Christian regime of truth in the context of Foucault's concept of strategic formations. The main emphasis is on the sexual formation of power in three focal points of its agency. The first focal point is formed around the conflict between the Old Testament truth regime and the Canaan cult of fertility. The second focal point is formed around the influence of ancient philosophical thought, primarily through the philosophy of stoicism, which sees abstinence from the sexual act as an opening to divine inspiration and around medical knowledge of antiquity. The third focal point is formed around control mechanisms of the Christian regime of truth through classification, regulation, prohibition, tariffing offences and corrections of doctrine. The main purpose of the formation of power is the vertical structuring of the regime of truth in its anthropomorphic and androcentric immanence.
\end{abstract}

Keywords

Christian regime of truth, Michel Foucault, strategic formation, sexual formation of power

Usp. U. Ranke-Heinemann, Eunuchs for the Kingdom of Heaven, str. 316-318.

117

Usp. Bernhard Häring, Kristov Zakon, sv. 3, Drugi dio posebne moralne teologije: slobodni u Kristu, preveli Karlo Prendivo, Velimi Valjan, Kršćanska sadašnjost, Zagreb 1986., str. 81-82.
118

Usp. P. Brown, The Body and Society, str. 86.

119

Usp. B. Häring, Kristov zakon, str. 363. 